DOI: 10.31695/IJASRE.2021.34122

Volume 7, Issue 12

December - 2021

\title{
Enforcement of Property Related Taxes Defaulters Using Information Systems: The Case of Tanzania
}

\author{
Justuce Muhoza Gration', Shubi Felix Kaijage ${ }^{2}$ and Mussa Ally Dida ${ }^{3}$
}

School of Computational and Communication Science and Engineering

Nelson Mandela African Institution of Science and Technology- Arusha, Tanzania

\begin{abstract}
Tax Evasion and delayed payments of property-related taxes are problems facing revenue departments in many governments all over the world resulting in low revenues collection from this source of revenue. Although the laws in African countries seem to provide adequate enforcement measures, some of them are politically unacceptable and therefore are not used in practice. This paper focuses on designing Information and Communication technology mechanisms for enforcing property-related tax defaulters. An application prototype has been developed to implement the designed mechanism. The data on existing information systems used in the administration and collection of property-related taxes were collected through face-to-face interviews with systems administrators in each sector involved. The collected data were modeled using Unified Modeling Language and the Design Science Research approach was used to aid the design of the proposed enforcement mechanism. The results show that property-related tax defaulters are automatically denied electricity service until all tax arrears are settled.
\end{abstract}

Key Words: Application Prototype, Enforcement Mechanism, Information Systems, Property-related taxes, Tax defaulters.

\section{INTRODUCTION}

The rapid growing of cities poses a question on how to finance the development projects like building infrastructures as well as improving service delivery to citizens. Under this circumstance city are now strategizing their local sources of revenues. Propertyrelated taxes are among of the favored local taxes worldwide. Excluding only Burkina Faso and Seychelles, all African countries already have some form of property-related tax in their legislation [1]. In many African countries including Tanzania, Propertyrelated taxes are annual taxes based on immovable property which include land, buildings and all permanent fittings made on land.

The year-to year level of property-related tax arrears caused by non-compliances among tax payers is a bottleneck to the contribution of property-related tax in revenue collection. Strict enforcement mechanism is essential for better tax compliances and successful tax collection system [2]. The enforcement mechanism for property-related taxes defaulters varies from country to country. Although African countries laws provide for numerous enforcement mechanisms and in some countries like Tanzania and South Africa contained in more than one law, many of these are infrequently applied [3]. The most common enforcement measures used by many African countries are seizure of properties and taking defaulters to civil court. This method is costly, and it may take some years settling a case [4]. Although the law seems to provide adequate enforcement measures, some of them are politically unacceptable and therefore are not used in practice. If there is absence of political will for payment enforcement and there is awareness among taxpayers that these measures are not always practiced, an adverse impact on voluntary compliance is unavoidable, especially when there is poor service delivery.

In the effort to overcome the impractical enforcement measures provided by laws, Tanzania through the government budget of 2020/2021, the Minister of finance, Planning and Administration announced a new policy of collecting property tax from buildings through the prepaid electricity metering system and the implementation of this commenced on 1st August 2021. The policy charges a flat rate of 1000 Tanzania shillings for normal buildings and 5000 Tanzania shilling for story buildings per month and this amount is directly deducted from the amount paid by the taxpayer when applying for electricity recharge token. This mechanism has been effective in recovering arrears but it has some challenges. The need for bank reconciliation between the 
utility service provider and the tax authority, forcing the tenants to pay taxes instead of building owners and reconfiguration of prepaid electricity metering system in case the government needs to change from flat rate method to value-based method are some of fundamentals challenges associated with this new enforcement mechanism. Therefore, still there is a need to implement better ICT-based enforcement measures to fully tap the potentials of property-related taxes. This paper extends the conceptual framework proposed by in press [5] to design ICT-based property-related taxes enforcement mechanism and develops an application prototype to implement the designed mechanism.

\section{REVIEW ON EXISTING PROPERTY-RELATED TAXES ENFORCEMENT MEASURES IN AFRICAN COUNTRIES}

In Gambia pursuing the debt through the courts to seize chattels and goods, selling the property of defaulters, and eventually imprisoning the defaulter have been taken as primary enforcement measure. This mechanism is both expensive and time consuming and is rarely used. The impracticability of these measures is giving room for many property-related taxpayers to defaulter causing lower revenue collection from this source [6].

In Congo, the interest of 8 percent per month including penalties for all arrears of all amounts that need to be paid to the office of General Tax is incurred [7]. Prosecution measures can be taken to any taxpayer for not paying taxes on time. However, before prosecution, revenue receive sends the final warning to taxpayer, demanding payment in two weeks. After that, the revenue authority if necessary under the circumstances, sends a summons demanding the taxpayer to make payment in eight days on penalty of seizure of the possessed immovable and movable assets. The revenue receiver can proceed with the seizure after that period expired [8].

In Gabon, the following enforcement measures against potential tax evaders are allowed by the legislation; the interest of 10 percent on arrears the tax liability is charged when a taxpayer denies to pay by the last day of the second month subsequent to the month when the notifications corresponding property tax bill were released. Consequently, the receiver of the tax will apply a 1 percent increase each month the tax liability is not settled [9]. The legislation also allows for the property to be seized and sold at a public auction [10].

Local Government Act Section 106(1) in Ghana orders that when the amount of the specific or general rate due on any buildings is not paid inside forty-two days, the assembly of the district may request to a court for an order for the sale of the buildings [11]. Principally, this enforcement measure would seem to be direct due to the fact that government normally knows the property owner's location and can directly access the property in case of nonconformity. In actual sense, this enforcement is weak and the main barriers to are political and social factors.

The Rating Act of Kenya deals with measures for enforcing defaulters to pay their rates. When an eligible owner default to make payment in the given period, there exist several legal mechanisms to ensure compliance, including arrears interest, foreclosures, fines, tax liens, and regaining from tenants [12]. These measures, however, are infrequently used and are ineffective in realizing compliance. Instead of taking this aggressive action of enforcement, county governments depend on denying the renewal of business license [13]. The Business license is a helpful mechanism of enforcement because it will require taxpayer to clear in advance any tax arrears before the new license is issued but this will not cover the property owners who does not have any business.

In Liberia taxes on penalties, real property, interest, and other charges that may be charged on any property continue to be unsettled until they are paid. Such unsettled taxes take preference over all other charges involved on the real property. Lawbreaking are submitted to the Minister of Justice for the Tax Court measures [14]. This confrontational process is cumbersome, costly, and ineffective. Currently, enforcement efforts mostly target properties owned on commercial usage. In the long term, this exercise may root the impression that owners of residential properties are not supposed to pay their taxes [15]. Appropriate enforcement remains a severe problem because putting provisions of the law into serious actions could create social unrest.

In Namibia, to ensure compliance, formal transfer of property is allowed only after tax clearance certificates are acquired. Additionally, the Act of Local Authorities provides that authority at the local level may impose interest on any delayed rates at a rate not exceeding the prescribed rates under the provisions of the Prescribed Rate of Interest Act No. 55 of 1975 [16]. The law also provides for public sale and seizure of properties accumulating arrears for the period of three or more years. Apparently this measure is unused [17]. 
In Rwanda, arrears can be claimed before the court measures. Under the area of jurisdiction of the fixed asset, the district has the right to attach to the taxpayer the rent owed by a tenant up to the amount of outstanding tax; use third parties to attach money owed to taxpayer; sell and seize movable assets owned by the taxpayer; or sell and seize fixed assets owned by the taxpayer [18].

The Local Government Act in Sierra Leone provides that for property tax noncompliance, city council mayor may instruct the bailiff to seize the property and sell it in public auction to the maximum bidder within 20 days. If after this process the whole property tax amount payable is not recovered, the mayor is mandated by the law to give other warrant ordering the bailiff to claim settlement of the unpaid property tax part from the property occupier (if any). However, the primary obstacle to enforcement is the system politicization. Despite the fact that defaulters names are published occasionally in local newspapers, defaulters court measures have been very infrequent due to lack of political will, since majority of owners of properties are rich and have good connections with the political elite [19]. The Strong connections among big landowners and political elites is the primary explanation for low collections from property taxes in developing countries [20].

In Uganda, Local governments can enforce property taxes payment by several means, like demand notices distribution, penalties and interest, recovery from tenants and occupiers, transfer of a property prohibition, and putting a first charge on a property. These measures are underused, and enforcement efforts are generally low [21]. Impracticable enforcement provisions abound, and enforcement against absentee property owners is lengthy and costly.

In Tanzania, the Urban Authorities (Rating) Act of 1983 and the Local Government Finance Act of 1982 provide procedures for enforcing compliance to property taxpayers. The legal provisions that are available to councils to enforce rates compliance include penalty charged at a rate not exceeding 1 percent per month on the unpaid rates. A distrait on the chattels and personal goods of defaulters. Sale of the buildings of those defaulters whose rates are in arrears. Deductions from defaulter's salary to recover unpaid rates. A 25 percent penalty per year of the amount of tax in arrears or imprisonment of defaulters for at most 12 months' term, or both [20]. Although legislation provides for various enforcement mechanisms, implementing them by local authorities to enforce property tax compliance is a challenging task. The time consuming and expensive nature of legal procedures combined with limited resources are the primary barriers for local authorities to apply enforcement legislation [22].

\section{METHODOLOGY}

The study involved the collection of primary data from Tanzania Electricity Supply Company (TANESCO), Tanzania Revenues Authority (TRA) and Ministry of Lands, Housing and Human Settlements Development through face-to-faces interviews with systems administrators in Dodoma and Dar Es Salaam in order to gain understanding on how property-related taxes information systems involved in the designed mechanism are used in administration and collection of taxes. The data from systems administrators in TANESCO were used to gain understanding on how the prepaid metering system works. The secondary data from relevant sources such as textbooks, Journals and official Documents were also used to gather information about legal and administration enforcement measures used to enforce property-rated tax defaulters. The collected data were modeled using Unified Modeling Language (UML) and Agile Programming were used to develop the application prototype to implement the designed mechanism. The Design Science Research (DSR) approach was used in designing the proposed mechanism. DSR is fundamentally problem-solving paradigm which works on conceptualizing and understanding the problem and attempts to find the solution for such a problem [23]. During solutions finding to the problems, DSR contributes to motivating design science knowledge or creates new artifacts in an area of attention [24]. The artefacts can be defined as constructs - symbols and vocabulary, models - representations and abstractions, methods - practices and algorithms, and instantiations - prototype s and implemented systems [23]. The DSR produces Innovations intended to solve society problems in real world and make contributions to the theory of the discipline in which it is applied [25].

\section{FRAMEWOEK FOR PROPOSED ENFORCEMNT MECHANISM}

In Tanzania, each building in urban areas is charged annually tax called property tax and each surveyed plot of land is charged annually tax called land rent. These two kind of taxes are the ones termed as property-related taxes. The building is erected on a plot of land and both the building and the plot of land are charged annually taxes. The electricity Prepaid Meter is connected to the building for providing electricity service to the building owner. Figure 1 shows the framework which links the electricity prepaid metering system with property- related taxes information systems to provide electronic enforcement mechanism by denying electricity services to defaulters until when arrears are cleared.

The necessary changes made on property-related taxes information systems for this framework to work is to include for each building and plot owner the information about the connected electricity prepaid meter. When the electricity consumer (taxpayer) 
request for electricity recharge token, the prepaid electricity metering system will first connect to the property-related taxes information systems to check for any tax arrears. The recharge token will only be delivered to consumers with no any propertyrelated tax arrears. Otherwise the information about the arrears will be returned to those defaulters directing them to pay their tax arrears first and then re-request for the electricity recharge token.

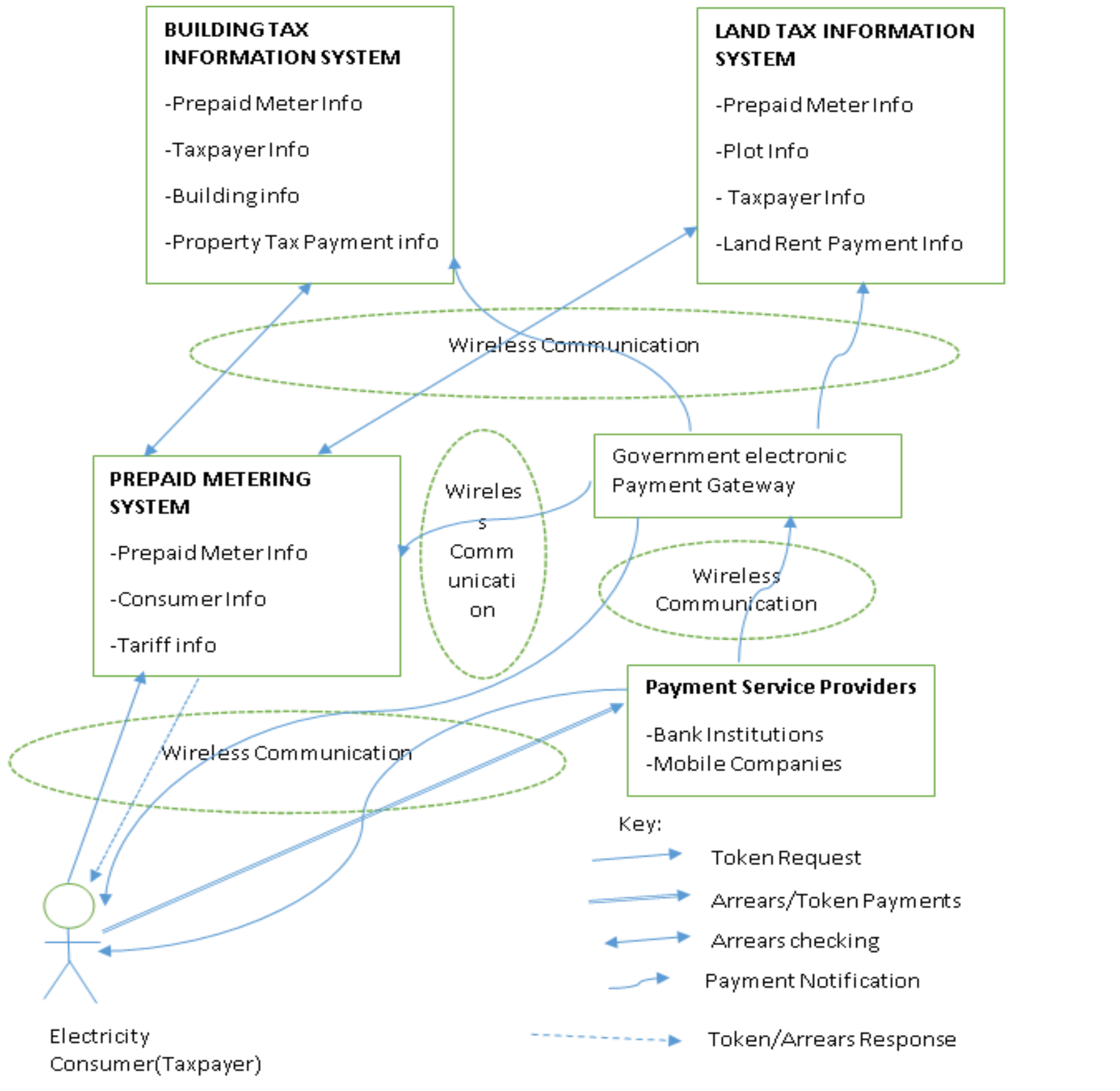

Figure 1: Framework for the proposed enforcement mechanism (designed by the authors)

\section{APPLICATION PROTOTYPE IMPLEMENTING THE PROPOSED ENFORCEMENT MECHANISM}

UML sequence diagrams was used to model the gathered requirements used for the development of the application prototype which implements the designed enforcement mechanism. They show interactions between actors and system objects on its environment. They present communication sequences that take place during the run of the system and highlight the messages exchanged during system run. Sequence diagram is a common notation specifying scenarios of operations processing and help in understanding of the system behavior [26]. 


\subsection{Electricity consumer with tax arrears}

Figure 2 shows the sequence diagram for the electricity consumer having tax arrears requesting for electricity recharge token. From the diagram, once the Prepaid Metering System (PMS) receives the token request, it first checks for the correctness of the received electricity meter number and then connect to the Building Tax (BTS) and Land Tax (LTS) Information Systems to check if the consumer has any arrears and respond with arrears message.

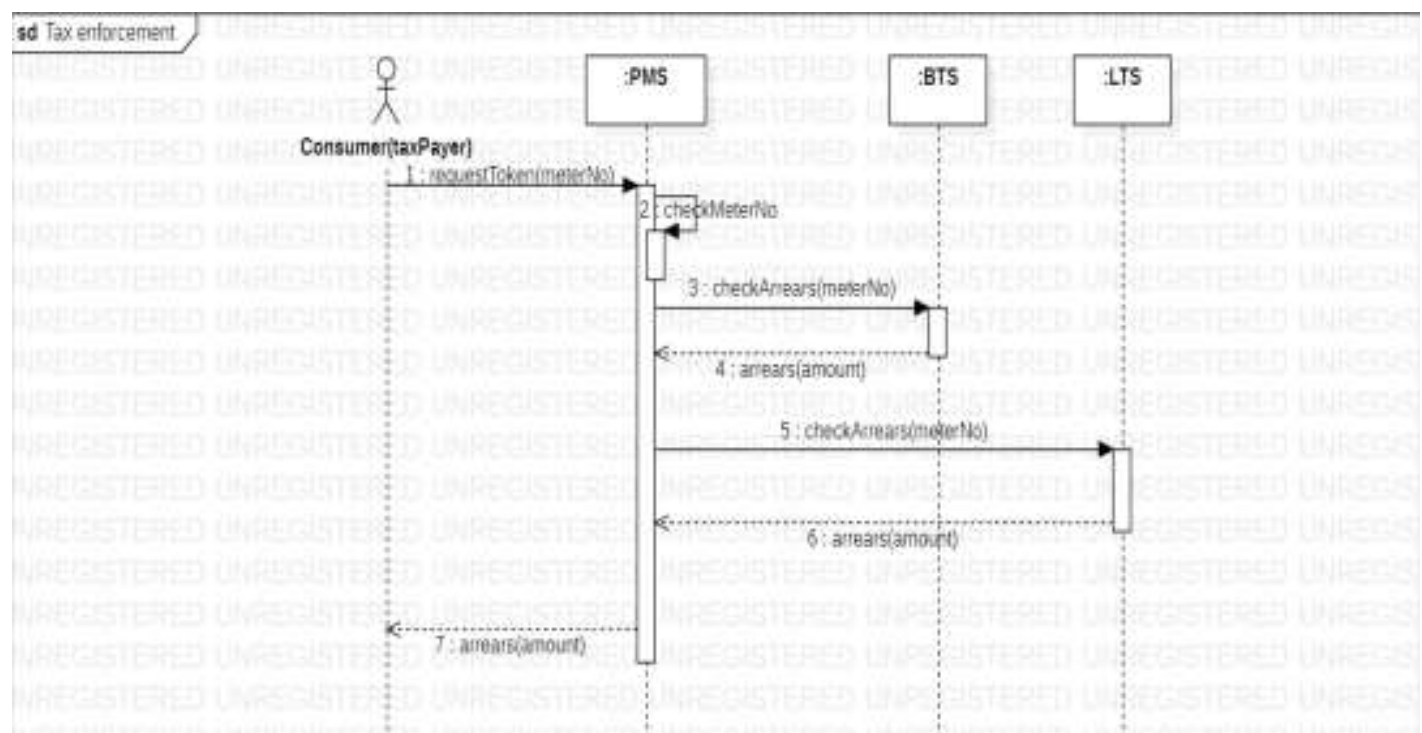

Figure 2: Sequence diagram for consumer with tax arrears (designed by the authors)

\subsection{Tax arrears payment}

After the electricity consumer has received the tax arrears from the prepaid metering system, he will need to pay for the received arrears to the authority concerned in order to get electricity services. The consumer connects to the BTS to make the payment of building tax arrears. Figure 3 shows the objects involved and necessary communication between them to accomplish the payment process. The same process is followed when paying for land tax arrears by connecting to LTS instead of connecting to BTS.

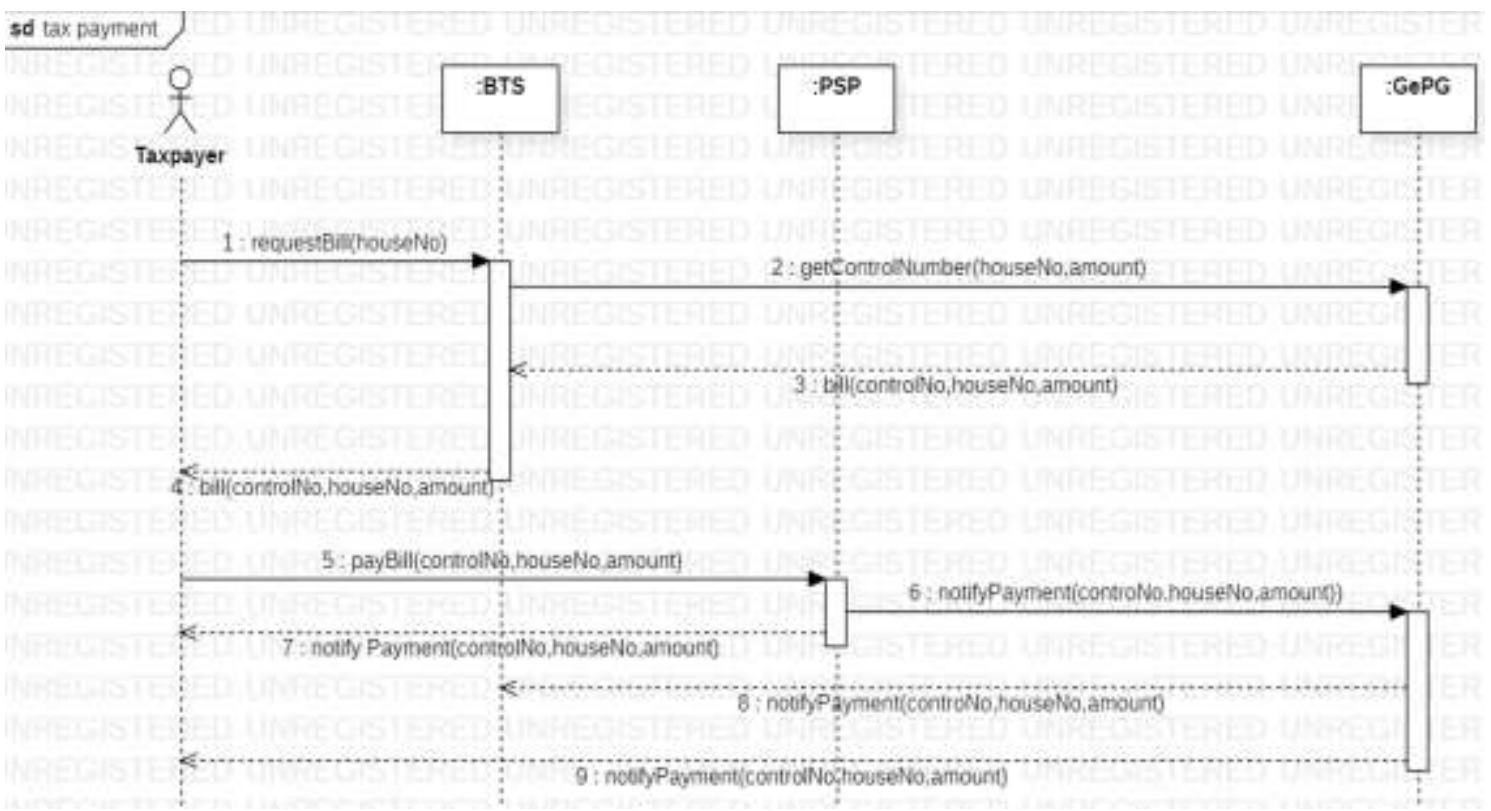

Figure 3: Sequence diagram for building tax arrears payment (designed by the authors)

\subsection{Electricity consumer with no tax arrears}

Figure 4 shows the sequence diagram for the electricity consumer with no any tax arrears requesting for electricity recharge token. From the diagram, once the PMS receives the token request and checks for the correctness of the received electricity meter 
number, it connects to the BTS and LTS Information systems to check if the consumer has any arrears. Since this consumer has no arrears, the prepaid metering system request the consumer to pay for the token. The consumer connects to Payment Service Provide (PSP) and make payments. The PSP after receiving the payments notifies the consumer and the Government Electronic Payment Gateway (GePG) of the paid amount. The GePG notifies the PMS which delivers the recharge token to the consumer.

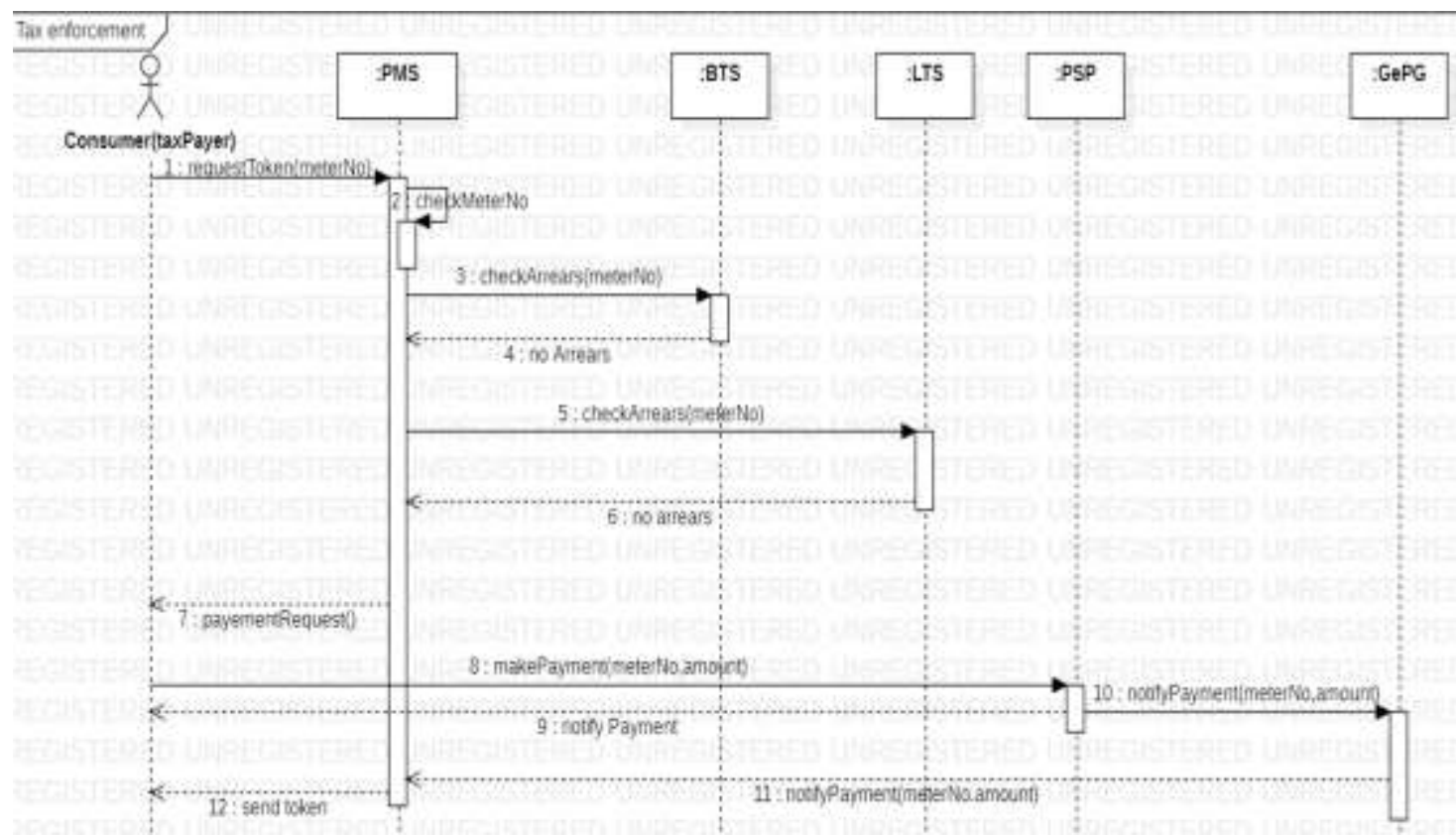

Figure 4: Sequence diagram for consumer with no tax arrears (designed by the authors)

\section{RESULTS AND DISCUSSION}

The electricity consumer connected to the national grid using prepaid electricity meter number 2267897 having building tax arrears of TSH 12000 and land tax arrears of TSH 70000 is used to demonstrate the results of the developed application prototype. The prepaid meter is installed on a house constructed on a piece of land with plot number 48 and block DD. Figure 5 shows the token request form.

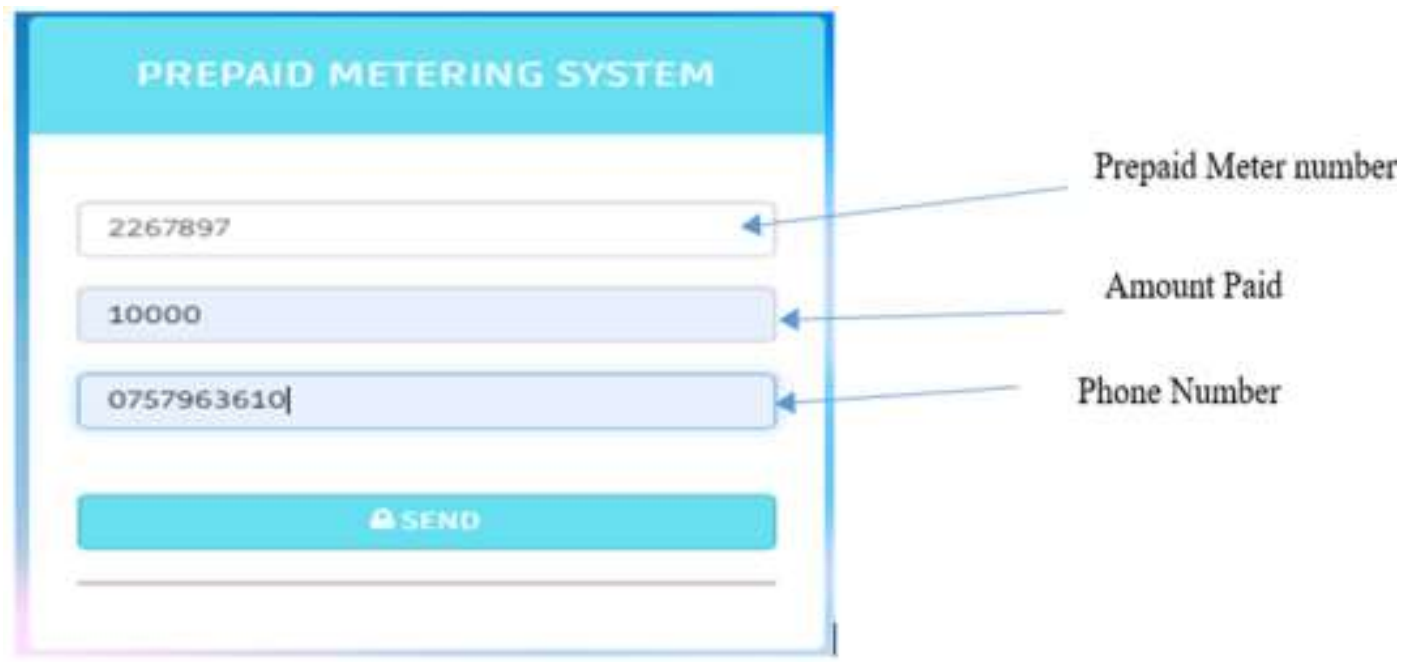

Figure 5: Electricity token request form (developed by the authors)

Once this information in Figure 5 is submitted, the prepaid metering system will use the meter number to connect to building tax information system and land tax information system to check for tax arrears and respond accordingly. Figure 6 shows the results after submitting the information. 


\section{PREPAID METERING SYSTEM}

You have Denied Electricity Services. Your must first clear your property tax arrears of Tsh 12000 and land rent arrears of Tsh 70000

Figure 6: Prepaid metering system arrears response (developed by the authors)

To be able to get electricity service, the consumer must first clear all the tax arrears. Figure 7 shows a form used for payment of building tax arrears. Similar form is filled when paying for land tax arrears.

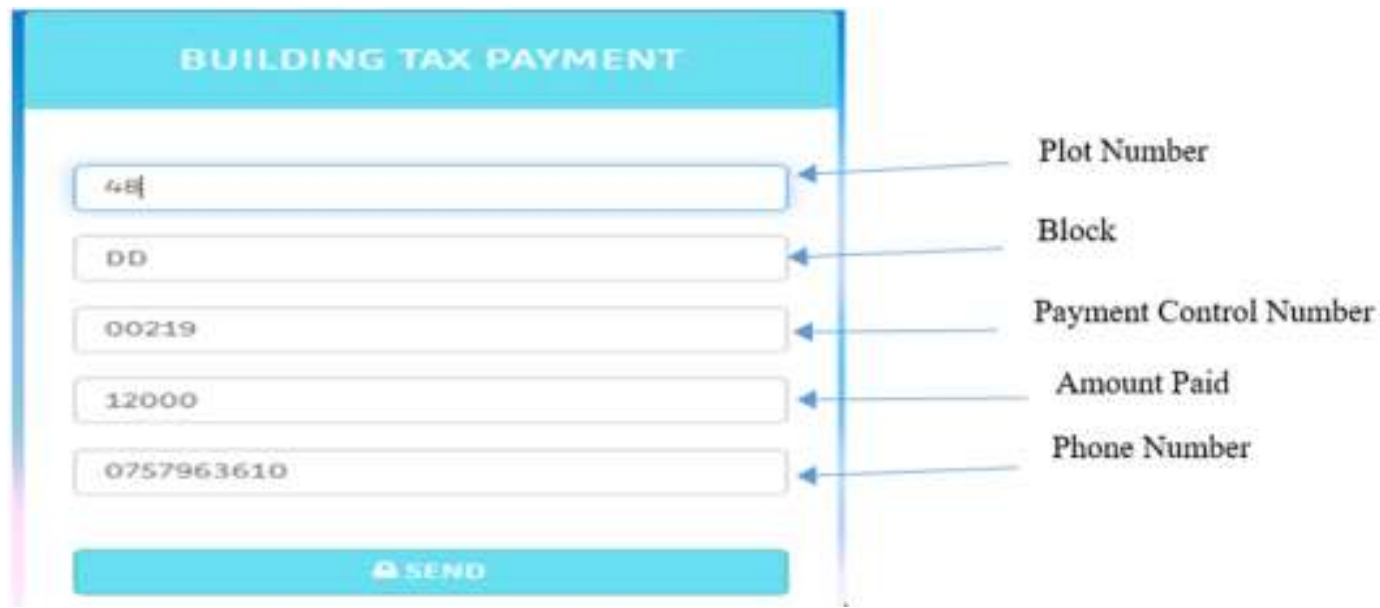

Figure 7: Building tax payment form (developed by the authors)

After filling the information and sending them the taxpayer will be notified by the receiver that payment has been successfully received as shown in Figure 8.

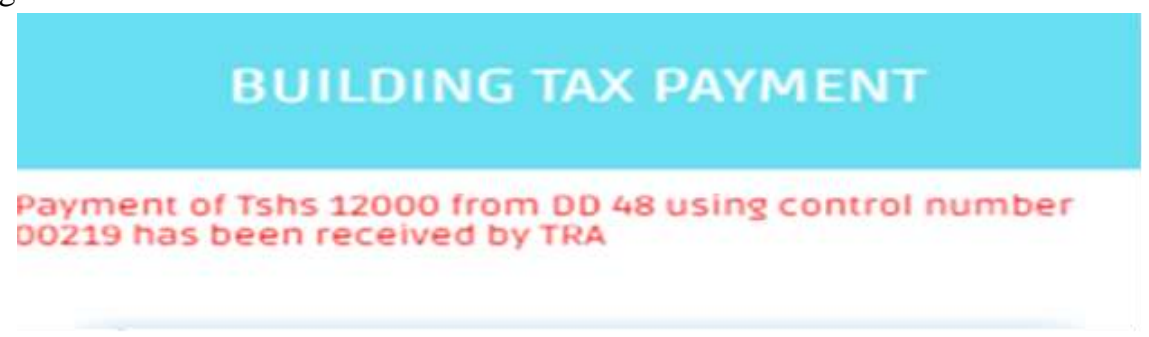

Figure 8: Building tax payment response (developed by the authors)

After the payment of all the arrears, the consumer can request again for the recharge token. Figure 9 shows response from the prepaid metering system providing the recharge token to the consumer. The consumer enters the received recharge taken into the prepaid electricity meter and continues to use electricity.

\section{PREPAID METERING SYSTEM}

Amount paid $=$ TSH 10000 Units Recieved $=33.3 \mathrm{KWH}$ token: 100521095153401330

Figure 9: Prepaid metering system token response (developed by the authors)

\section{LIMITATION OF THE PROPOSED ENFORCEMENT MECHANISM}


Under the government initiatives to make sure that all parts of the country including villages in rural areas are connected to the national grid, this proposed mechanism will affect a big number of property-related taxpayers and enable the authority to collect more revenues from this source. Property owners whose plots are not yet developed or whose developed plots are not yet connected the national grid are not covered by this mechanism. Under this circumstance, the tax authorities can still use the available legal and administration enforcement measures to enforce defaulters belonging in this category. This will need fewer resources and less collection costs since the majority of defaulters will be covered by the framework.

\section{CONCLUSION}

Tax payments are always not voluntary for the majority of tax payers and most of them are paying taxes to comply with the polices and regulations and when there are some enforcement measures to make them pay taxes. Strict enforcement mechanism is essential for better tax compliances and successful tax collection system. Different from other taxes like cooperate income taxes, social insurance taxes, taxes on goods and services which are easy to enforce, the enforcement of property tax defaulters is very complex due to impractical and political infeasible administration and legal enforcement measures present in many governments' laws and regulations specifically in African countries. This paper has leapfrogged the evolution of Information and Communication Technology (ICT) by utilizing existing Information Systems used in collection and administration of propertyrelated taxes in Tanzania to design ICT-based enforcement mechanism. The results of the developed applications prototype have shown that the electricity consumer with delayed property-related tax payments is automatically denied electricity services until the rates are cleared

\section{ACKNOWLEDGMENT}

The authors of this work would like to acknowledge Local Government Training Institute (LGTI) for funding this research.

\section{REFERENCES}

[1] A. Haas, “An overview of municipal finance in Hargeisa, Somaliland," Hargeisa, 2017. [Online]. Available: https://www.theigc.org/wp-content/uploads/2018/01/201712HargeisaMunicipalFinanceWP_Final2.pdf.

[2] W. Prichard, "Taxation, governance and growth," GSDRC Prof. Dev. Read. Pack, vol. 43, 2016, [Online]. Available: http://www.gsdrc.org/wp-content/uploads/2016/06/Taxation-governance-and-growth_RP.pdf.

[3] R. Franzsen and W. McCluskey, Property Tax in Africa: Status, Challenges, and Prospects. Lincoln Institute of Land Policy, 2017.

[4] F. Plimmer and W. McCluskey, "Property Taxation for Developing Economies,” Copenhagen:, 2016.

[5] J. Gration, S. Kaijage, and D. Mussa, "Utilization of Information and Communication Technology in Addressing Property Tax Collection Challenges: The Case of Tanzania," 2021.

[6] CIA (Central Intelligence Agency), “The Gambia,” World Factb., 2016, [Online]. Available: https://www.cia.gov/library/publications/the-world-factbook/geos/ga.html.

[7] J. Nzewanga, "Property Taxation in the Democratic Republic of the Congo," Work. Pap. WP09FAB3. Cambridge, MA Lincoln Inst. L. Policy, 2009.

[8] CIA (Central Intelligence Agency), “Congo,” World Factb., 2016, [Online]. Available: https://www.cia.gov/library/publications/the-world-factbook/geos/li.html.

[9] L. A. Wily, Land Rights in Gabon: Facing up to the Past and Present. Brussels, Belgium:FERN, 2012.

[10] N. Monkam, "Property Tax as Legislated and Practiced in Gabon.," J. Prop. Tax Assess. Adm., vol. 8, no. 2, pp. 53-69, 2011.

[11] J. Z. Ayitey, E. Kuusaana, K. J, and Kidido, "Potentials and Hurdles in Property Rating in Ghana: Evidence from the Wa Municipality," Ghana Surv., vol. 5, no. 1, pp. 1-13, 2013.

[12] R. Franzsen, Policy Issues and Options: Taxation Laws for Kenya's County Governments. Washington, DC: World Bank, 2013.

[13] CIA (Central Intelligence Agency), “Kenya.’In The World Factbook,” 2016. [Online]. Available: https://www.cia.gov/library/publications/the-world-factbook/geos/ke.html.

[14] O. Olabisi, "Optimising Real Estate Tax in Liberia: Implications for Revenue Performance and Economic Growth,” Work. 
Pap. London Int. Growth Centre., 2013.

[15] CIA (Central Intelligence Agency)., “'Liberia.’ In The World Factbook,” 2016. [Online]. Available: https://www.cia.gov/library/publications/the-world-factbook/geos/li.html.

[16] R. Franzsen, "Property Taxation Within the Southern African Development Community (SADC): Current Status and Future Prospects of Land Value Taxation, Botswana, Lesotho, Namibia, South Africa, and Swaziland," Work. Pap. WP03RF1 Cambridge, MA Lincoln Inst. L. Policy, 2003.

[17] S. Jibao, "A Comprehensive Review of the Administration of Property-Related Taxes in Namibia," Draft Work. Pap. African Tax Inst. Lincoln Inst. L. Policy, 2010.

[18] M. Cyan, C. Karuranga, and F. Vaillancourt, Local Government Revenue Potential in Rwanda. Atlanta: Andrew Young School of Policy Studies, Georgia State University., 2013.

[19] P. Fish, "Practical aspects of mobilising property tax: experience in Sierra Leone and Malawi," Commonw. J. Local Gov., vol. 17 , no. 16, pp. 242-262, 2015, doi: 10.5130/cjlg.v0i0.4591.

[20] A. Tommy, R. Franzsen, and S. Jibao, "Property Taxation in Sierra Leone: Current Practices, Performance and Options for Reform," 2015.

[21] W. Olima and H. A, "Property Taxation in Anglophone East Africa: Case Study of Tanzania," Cambridge, MA, WP10NEA7, 2010.

[22] CIA (Central Intelligence Agency), “'Tanzania.’ In The World Factbook,” 2016. [Online]. Available: https://www.cia.gov/library/publications/the-world-factbook/geos/tz.html.

[23] A. Hevner, S. Ram, S. March, and J. Park, "Design Science in Information Systems Research,” MIS Q., vol. 28, no. 1, pp. 75-105, 2004.

[24] V. Vaishnavi and W. Kuechler, Design Research in Information Systems. 2004.

[25] K. Lukka, “The Constructive Research Approach: Case Study Research in Logistics,” Publ. Turku Sch. Econ. Bus. Adm., vol. B, no. 1, pp. 83-101, 2003.

[26] N. Oksana, K. Ludmila, and D. Ahilcenoka, "UML Sequence Diagram: Transformation from the Two-Hemisphere Model and Layout," Appl. Comput. Syst., vol. 14, no. 1, pp. 31-41, 2013, doi: 10.2478/acss-2013-0004.

\section{AUTHORS' PROFILE}

1. Justuce Muhoza Gration is a PhD candidate in School of Communication and Computational Science and Engineering, specializing in Information Technology Systems Development and Management at Nelson Mandela African Institution of Sciences and Technology. He has Masters Degree in Telecommunications Engineering from University of Dodoma and Bachelor Degree in Computer Science from University of Dar es Salaam-Tanzania. Email: grationj@nm-aist.ac.tz

2. Shubi Felix Kaijage received his Doctor of Engineering degree (Electronics and Information Eng.) and Master in Engineering (Electrical and Electronics Eng.) degrees from University of the Ryukyus, Okinawa, Japan. He works as a senior lecturer and Acting Dean in the School of Computational and Communications Science and Engineering (CoCSE), the Nelson Mandela African Institution of Science and Technology (NM-AIST). He has published over 40 scientific papers in international peer- reviewed journals and more than 50 research papers presented in various international conferences. Furthermore, he is a recipient of numerous international awards and grants as recognition to his scholarly works. Shubi is the member of international professional societies including the Institute of Electrical and Electronics Engineering (IEEE), African Academy of Sciences, and the Optical Society of America (OSA). His specialization and research interests are in Optics and Photonics, Optical fiber and photonic crystal fibers (PCFs), Optoelectronics, and Wireless Sensor Networks. Email: shibi.kaijage@nm-aist.ac.tz

3. Mussa Ally Dida is a Senior Lecturer at Nelson Mandela African Institution of Science and Technology (NM-AIST) and a Deputy Centre Leader of a Centre of Excellence for ICT in East Africa (CENIT@EA). He acquired his PhD in Information and Communication Engineering from Beijing Institute of Technology (BIT), Beijing, China. His Masters of Science in Telecommunication Engineering was from University of Dodoma and his B.Sc. in Computer Engineering and Information Technology were obtained from University of Dar es Salaam (UDSM). His research interests include signals and communication systems analysis, modeling, and optimization and Communication systems development. Email: mussa.ally@nm-aist.ac.tz 